\title{
Efek Pemberian Ekstrak Daun Sirsak (Annona muricata L.) terhadap Gambaran Histopatologik Hati Tikus Wistar (Rattus Norvegicus) yang Diinduksi Rifampisin
}

\author{
${ }^{1}$ Vega F. S. Parapaga \\ ${ }^{2}$ Meilany F. Durry \\ ${ }^{2}$ Poppy M. Lintong
}

\author{
${ }^{1}$ Program Studi Pendidikan Dokter Fakultas Kedokteran Universitas Sam Ratulangi Manado \\ ${ }^{2}$ Bagian Patologi Anatomi Fakultas Kedokteran Universitas Sam Ratulangi Manado \\ Email: vegaparapaga@gmail.com
}

\begin{abstract}
Soursop leaves can be used as hepatoprotector because its flavonoid content has antioxidant activity that can inhibit and prevent liver damage. This study was aimed to obtain the effects of administration of soursop leaf extract on the histopathological features of the liver of Wistar rat induced by rifampicin. This was an experimental study using 20 Wistar rats divided into four groups. The negative control (A) group were not given any treatment; the B group was given rifampicin $1 \mathrm{~g} / \mathrm{kgBW} /$ day for 14 days; the $\mathrm{C}$ group was given rifampicin $1 \mathrm{~g} / \mathrm{kgBW} /$ day for 14 days followed by the administration of soursop leaf extract $400 \mathrm{mg} / \mathrm{kgBW} /$ day for the next 7 days; and the D group was given rifampicin $1 \mathrm{~g} / \mathrm{kgBW} / \mathrm{day}$ for 14 days followed by the administration of soursop leaf extract $600 \mathrm{mg} / \mathrm{kgBW} /$ day for the next 7 days. The $\mathrm{A}$ and $\mathrm{B}$ groups were terminated at day 15, while the $\mathrm{C}$ and $\mathrm{D}$ groups were terminated at day 22. The microscopic examination revealed that the $\mathrm{NC}$ group had normal liver feature. The $\mathrm{B}$ and $\mathrm{C}$ groups exhibited the presence of necrotic liver cells and cloudy swelling. Meanwhile, the D group showed regenerating liver cells. Conclusion: The liver of Wistar rats that were given soursop leaf extract dose $600 \mathrm{mg} / \mathrm{kgBW} /$ day after rifampicin induction showed regenerating liver cells.
\end{abstract}

Keywords: rifampicin, soursop leaves, liver, histopathologic

\begin{abstract}
Abstrak: Daun sirsak dapat dimanfaatkan sebagai hepatoprotektor karena kandungan flavonoidnya memiliki aktivitas antioksidan yang mampu menghambat dan mencegah kerusakan oksidatif hati. Penelitian ini bertujuan untuk mengetahui efek pemberian ekstrak daun sirsak terhadap gambaran histopatologik hati tikus Wistar yang diinduksi rifampisin. Jenis penelitian ialah eksperimental, menggunakan 20 ekor tikus Wistar yang dibagi dalam empat kelompok. Kelompok kontrol negatif (A) tidak diberi perlakuan selama 14 hari; kelompok B diberi rifampisin $1 \mathrm{~g} / \mathrm{kgBB} /$ hari selama 14 hari; kelompok $\mathrm{C}$ diberi rifampisin $1 \mathrm{~g} / \mathrm{kgBB} /$ hari selama 14 hari dilanjutkan dengan pemberian ekstrak daun sirsak 400mg/ $\mathrm{kgBB} /$ hari selama 7 hari; dan kelompok D diberi rifampisin $1 \mathrm{~g} / \mathrm{kgBB} /$ hari selama 14 hari dilanjutkan dengan pemberian ekstrak daun sirsak $600 \mathrm{mg} / \mathrm{kgBB} /$ hari selama 7 hari. Tikus kelompok A dan B diterminasi pada hari ke-15, sedangkan kelompok C dan D diterminasi pada hari ke-22. Hasil penelitian menunjukkan gambaran histopatologik hepar tikus Wistar yang normal pada kelompok A, sedangkan pada kelompok B dan C tampak adanya sel-sel hati yang mengalami nekrosis dan degenerasi bengkak keruh. Pada kelompok D terlihat adanya sel-sel hati yang mengalami regenerasi. Simpulan: Hati tikus Wistar yang diberikan ekstrak daun sirsak dosis $600 \mathrm{mg} / \mathrm{kgBB} / \mathrm{hari}$ setelah pemberian rifampisin menunjukkan gambaran selsel hati yang mengalami regenerasi.
\end{abstract}

Kata kunci: rifampisin, daun sirsak, hati, gambaran histopatologik 
Berdasarkan penelitan di Amerika Serikat terdapat sekitar 2000 kasus gagal hati akut yang terjadi setiap tahunnya dan lebih dari $50 \%$ disebabkan oleh obat. ${ }^{1}$ Obat-obatan tersebut memiliki efek hepatotoksik yang menginduksi kerusakan hati atau yang lebih sering dikenal dengan drug induced liver injury (DILI). ${ }^{2}$ Salah satu obat yang mempunyai efek hepatotoksik yaitu rifampisin. Rifampisin ialah obat antibiotik yang digunakan untuk terapi tuberkulosis (TB), tetapi bersifat hepatotoksik. Penggunaan obat ini tetap menjadi masalah yang signifikan untuk pengobatan klinis. ${ }^{3}$

Untuk mengurangi reaksi hepatotoksik dari obat, tubuh membutuhkan antioksidan sebagai hepatoprotektor. Salah satu bahan antioksidan yang dapat mengurangi efek hepatotoksik ialah tanaman sirsak (Annona muricata Linn.). ${ }^{4}$ Bagian dari tanaman sirsak yang dapat dimanfaatkan sebagai hepatoprotektor ialah daun sirsak. Beberapa penelitian menyatakan bahwa daun sirsak memiliki aktivitas antioksidan yang mampu menghambat dan mencegah kerusakan oksidatif hati. ${ }^{5}$ Jenis senyawa kimia yang terkandung dalam daun sirsak antara lain: flavonoid, alkaloid, dan saponin.

Tujuan penelitian ini untuk mengetahui efek pemberian ekstrak daun sirsak terhadap gambaran histopatologik hati tikus Wistar yang diinduksi rifampisin.

\section{METODE PENELITIAN}

Jenis penelitian ini ialah eksperimental laboratorium yang dilakukan di Laboratorium Patologi Anatomi Fakultas Kedokteran Universitas Sam Ratulangi Manado.

Subyek penelitian ialah 20 ekor tikus Wistar jantan berumur 2-3 bulan dengan berat rerata 150 gram. Pada penelitian ini digunakan ekstrak daun sirsak dan rifampisin. Ekstrak daun sirsak yang digunakan yaitu dosis $400 \mathrm{mg} / \mathrm{kgBB} / \mathrm{hari}$ dan $600 \mathrm{mg} /$ $\mathrm{kgbb} / \mathrm{hari}$. Obat rifampisin yang di-gunakan ialah tablet $450 \mathrm{mg}$ yang dijual bebas dengan dosis $1 \mathrm{~g} / \mathrm{kgBB} /$ hari. Ekstrak daun sirsak dan rifampisin dilarutkan menggunakan akuades lalu diberikan secara oral menggunakan sonde lambung khusus untuk tikus.
Subyek penelitian dibagi dalam empat kelompok, yaitu satu kelompok kontrol negatif dan tiga kelompok perlakuan, masing-masing kelompok terdiri dari 5 ekor tikus. Kelompok A (kontrol negatif) tidak diberikan perlakuan selama 14 hari. Kelompok B (Perlakuan I) diberikan rifampisin dengan dosis $1 \mathrm{~g} / \mathrm{kgBB} /$ hari selama 14 hari. Kelompok C (Perlakuan II) diberikan rifampisin dengan dosis $1 \mathrm{~g} / \mathrm{kgBB} /$ hari selama 14 hari kemudian dilanjutkan dengan pemberian ekstrak daun sirsak dengan dosis 400mg/kgBB/hari selama 7 hari. Kelompok D (Perlakuan III) diberikan rifampisin dengan dosis $1 \mathrm{~g} / \mathrm{kgBB} /$ hari selama 14 hari kemudian dilanjutkan dengan pemberian ekstrak daun sirsak dengan dosis $600 \mathrm{mg} /$ $\mathrm{kgBB} /$ hari selama 7 hari. Terminasi hewan uji dilakukan pada hari ke-15 dan hari ke22 untuk mengambil organ hati. Organ hati diproses untuk pembuatan preparat histopatologik dan diamati dengan mikroskop cahaya.

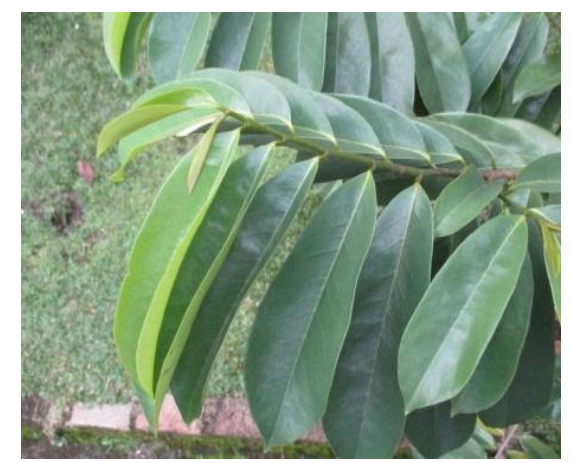

Gambar 1. Daun sirsak yang dipakai untuk pembuatan ekstrak

\section{HASIL PENELITIAN}

Kelompok A ialah kelompok tikus Wistar yang tidak diberikan perlakuan selama 14 hari, dan terminasi dilakukan pada hari ke-15. Gambaran mikroskopik hati tikus Wistar pada kelompok ini menunjukkan struktur dan susunan sel-sel hati yang normal (Gambar 2).

Kelompok B ialah kelompok tikus Wistar yang diberikan rifampisin dengan dosis $1 \mathrm{~g} / \mathrm{kgBB} /$ hari selama 14 hari. Didapatkan gambaran pembengkakan sel serta adanya sel hati yang mengalami nekrosis (Gambar 3A dan 3B). 


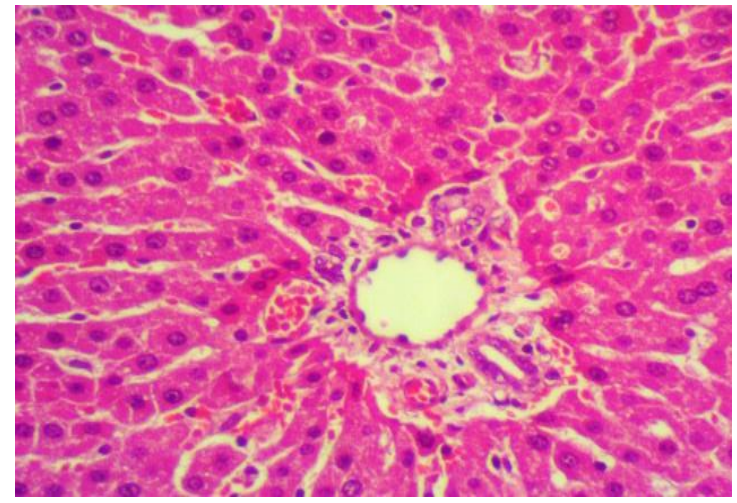

Gambar 2. Gambaran mikroskopik hati tikus Wistar kelompok A (kontrol negatif). Tampak gambaran hati normal, adanya vena sentralis, dan sel-sel hati yang tersusun radier dengan sinusoid di antaranya (Pembesaran 40x10)

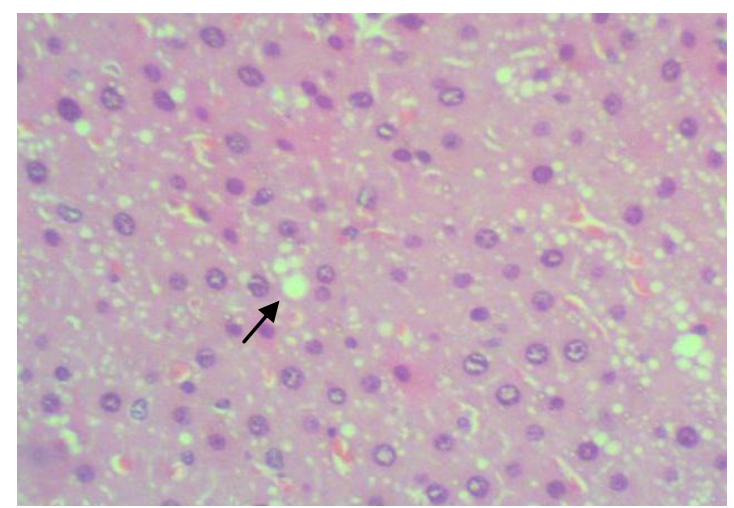

Gambar 3A. Gambaran mikroskopik hati tikus Wistar kelompok B (perlakuan I). Tampak gambaran sel hati dengan dinding sel yang tidak jelas dan terlihat adanya pembengkakan sel pada beberapa tempat (Pembesaran 40x10)

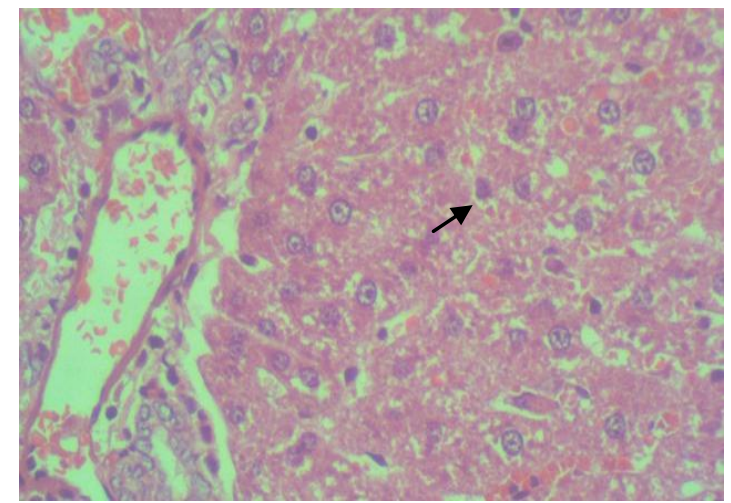

Gambar 3B. Gambaran mikroskopik hati tikus Wistar kelompok B (perlakuan I). Tampak gambaran sel hati yang mengalami nekrosis (pembesaran 40x10)

Kelompok C ialah kelompok tikus wistar yang diberikan rifampisin dengan dosis toksik $1 \mathrm{~g} / \mathrm{kgBB} /$ hari selama 14 hari kemudian dilanjutkan dengan pemberian ekstrak daun dengan dosis 400mg/kgbb/ hari selama 7 hari. Pada kelompok ini memberikan seperti pada kelompok B, yaitu tampak gambaran sel hati yang mengalami nekrosis serta tampak adanya gambaran pembengkakan sel (Gambar 4).

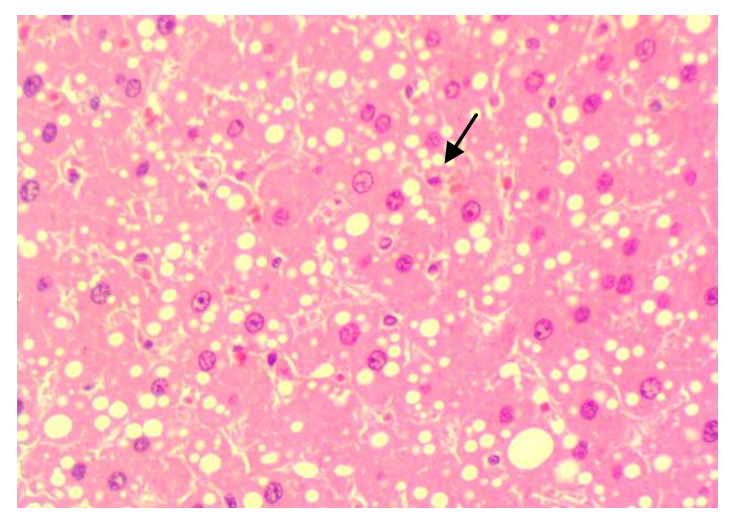

Gambar 4. Gambaran mikroskopik hati tikus Wistar kelompok B (perlakuan I). Tampak gambaran sel hati yang mengalami nekrosis (panah hitam) dan terlihat adanya pembengkakan sel pada beberapa tempat (pembesaran 40x10)

Kelompok D ialah kelompok tikus wistar yang diberikan rifampisin dengan dosis toksik $1 \mathrm{~g} / \mathrm{kgBB} /$ hari selama 14 hari kemudian dilanjutkan dengan pemberian ekstrak daun dengan dosis $600 \mathrm{mg} / \mathrm{kgbb} /$ hari selama 7 hari. Pada kelompok ini memberikan gambaran sel-sel hati yang telah mengalami regenerasi, ditandai dengan sel-sel hati berinti besar dengan nukleoli jelas dan berwarna homogen merah muda (Gambar 5).

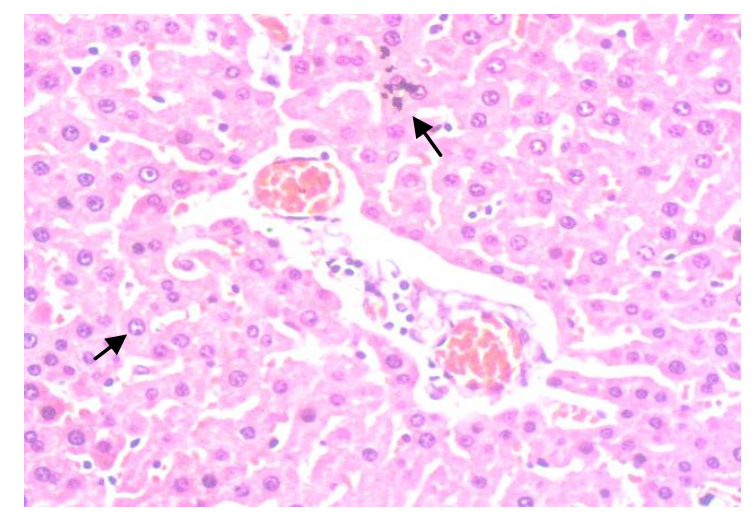

Gambar 5. Gambaran mikroskopik hati tikus kelompok D (perlakuan III). Terlihat sel-sel hati yang mengalami regenerasi ditandai oleh sel hati yang memiliki inti besar, sitoplasma meluas, berwarna homogen merah muda (pembesaran 40x10). 


\section{BAHASAN}

Kerusakan sel hati dapat disebabkan oleh berbagai faktor, salah satunya ialah penggunaan beberapa jenis obat secara terus-menerus dan tidak sesuai dengandosis yang dianjurkan. Salah satu contoh obat yang mempunyai efek hepatotoksikialah rifampisin. $^{2,3}$ Penelitian yang dilakukan ini memberikan informasi mengenai efek pemberian ekstrak daun sirsak terhadap gambaran histopatologik hati tikus Wistar yang diberikan rifampisin dengan membandingkan hasil tiap kelompok.

Hasil penelitian menunjukkan terdapat perbedaan gambaran mikroskopik antara hati tikus Wistar kelompok kontrol negatif dan kelompok perlakuan (Gambar 2-5). Pada tikus Wistar kelompok kontrol negatif ditemukan gambaran morfologik hati normal (Gambar 2). Perbedaan yang jelas terlihat antara hati tikus Wistar kelompok kontrol negatif (kelompok A) dan kelompok kontrol positif (kelompok B) yang diberi rifampisin selama 14 hari. Pada kelompok B jelas terlihat adanya sel-sel hati yang mengalami nekrosis serta adanya gambaran pembengkakan sel pada beberapa tempat (Gambar 3A dan 3B). Pada kelompok $\mathrm{C}$ (perlakuan II) yang diberikan rifampisin selama 14 hari kemudian dilanjutkan pemberian ekstrak daun sirsak dengan dosis $400 \mathrm{mg} / \mathrm{kgBB} /$ hari selama 7 hari juga menunjukkan gambaran mikroskopik yang sama dengan kelompok B (perlakuan I) (Gambar 4). Kerusakan ini terjadi karena rifampisin dengan aktivasi penginduksi poten sistem CYP450 yang memediasi generasi metabolit toksik obat dan ikatan kovalen ke makromolekul hati. Kerusakan sel hati terjadi karena rifampisin menginduksi stres oksidatif. Radikal bebas yang terbentuk akan berikatan dengan makromolekul hati yang nantinya akan menyebabkan kematian sel (nekrosis) (Gambar 3A). ${ }^{3}$ Dalam sebuah penelitian, dilaporkan terdapat peningkatan malondialdehyde (MDA) pada tikus yang diberikan rifampisin. Hal tersebut menunjukkan peningkatan peroksidasi lipid yang menyebabkan kerusakan jaringan. ${ }^{4}$ Pada gambaran mikroskopik tampak degenerasi bengkak keruh, ditandai oleh sel-sel hati dengan sitoplasma bervakuola.

Pada kelompok D (perlakuan III) yang diberi rifampisin selama 14 hari kemudian dilanjutkan dengan pemberian ekstrak daun sirsak dengan dosis $600 \mathrm{mg} / \mathrm{kgBB} / \mathrm{hari}$ selama 7 hari memberikan gambaran adanya sel-sel hati yang besar dengan sitoplasma meluas, berwarna homogen merah muda yang menunjukkan adanya regenerasi sel (Gambar 5). Hal ini dapat disebabkan oleh kerja antioksidan yang memiliki efek hepatoprotektor. Daun sirsak memiliki kandungan antioksidan golongan polifenol, salah satunya ialah flavonoid yang memiliki kemampuan mengubah atau mereduksi radikal bebas. Mekanisme aksi antioksidan flavonoid ialah dengan menekan pembentukan reactive oxygen species (ROS) misalnya dengan inhibisi enzimatik, menetralkan ROS, dan memberikan proteksi terhadap sistem pertahanan antioksidan tubuh. ROS adalah molekul yang sangat kecil dan sangat reaktif karena memiliki elektron tidak berpasangan. ROS dapat meningkat bila terjadi stres oksidatif. Flavonoid memiliki pengaruh ganda yaitu menghambat enzim yang bertanggung jawab atas produksi anion superoksida dan menghambat enzim yang termasuk dalam generasi ROS. Dengan demikian, tidak akan terbentuk radikal bebas yang dapat berikatan dengan makro-molekul jaringan hati sehingga kerusakan jaringan dapat dihindari. ${ }^{7}$

Senyawa antioksidan lain yang juga terdapat dalam daun sirsak yaitu alkaloid dan saponin. Senyawa-senyawa ini mampu memberikan perlindungan terhadap hati tikus yang terpapar oleh senyawa hepatotoksik seperti rifampisin. ${ }^{4,8}$ Secara keseluruhan, senyawa antioksidan seperti flavonoid, saponin, dan alkaloid yang terkandung dalam daun sirsak memiliki efek hepatoprotektor yakni dapat membantu menghambat proses terjadinya pembentukan radikal bebas sehingga tidak terjadi kerusakan oksidatif di dalam sel hati. ${ }^{3}$

Gambaran histopatologik yang berbeda antar kelompok hewan uji pada penelitian ini menunjukkan adanya pengaruh pembe- 
rian ekstrak daun sirsak dalam mencegah kerusakan sel hati akibat efek toksik rifampisin serta memicu terjadinya regenerasi sel hati.

Limitasi penelitian ini yaitu belum adanya penghitungan yang jelas mengenai dosis daun sirsak yang memiliki efek hepatoprotektor terhadap kerusakan hati. Namun demikian, hasil penelitian ini menambah informasi dan pengetahuan mengenai efek pemberian rifampisin dan daun sirsak terhadap organ hati.

\section{SIMPULAN}

Berdasarkan hasil penelitian ini dapat disimpulkan bahwa gambaran histopatologik hati tikus wistar yang diinduksi rifampisin dosis $1 \mathrm{~g} / \mathrm{kgBB} /$ hari selama 14 hari menunjukkan adanya kerusakan sel berupa degenerasi bengkak keruh dan nekrosis sel. Pemberian ekstrak daun sirsak dengan dosis $600 \mathrm{mg} / \mathrm{kgBB} / \mathrm{hari}$ selama 7 hari setelah induksi rifampisin menunjukkan gambaran regenerasi sel hati.

\section{SARAN}

Untuk penelitian selanjutnya disarankan untuk menggunakan beberapa jenis dosis dan durasi waktu yang berbeda sebagai perbandingan untuk mendapatkan dosis dan durasi waktu yang optimal.

\section{DAFTAR PUSTAKA}

1. Sonderup MW. Drug induced liver injury is a significant cause of liver disease, including chronic liver. Drug Induced Liver Injuries. 2007;29(6).

2. Zhao J. Protective effects of metallothionein on isoniazid and rifampicin-induced hepatotoxicity in mice. PLoSONE. 2013;8(8):720-58.

3. Lucena MI, Garcia-Cortes M, Cueto R, Lopez-Duran J, Andrade RJ. Assessment of drug-induced liver injury in clinical practice. Fundam Clin Pharmacol. 2008;22(2):141-58.

4. Sudarjanto. Manfaat sirsak. [cited 2018 Nov 22]. Available from: http://sudarjanto. multiply.com/journal/item /6695.

5. Gaze DC. 2007. The role of existing and novel cardiac biomarkers for cardioprotection. Curr Opin Investig Drugs. 2000;8(9): 711-7.

6. Swamy AHMV, Kulkarni RV, Koti BC, Gadad PC, Thippeswamy AHM, Gore A. Hepatoprotective effect of cissus quadrangularis stem extract against rifampicin-induced hepatotoxicity in rats. Indian J Pharm Sci. 2012;74(2):183-7.

7. Orbayinah, Salmah, Kartyanto A. Efikasi Binahong (Anredera cordifolia (Tenore) Steenis) terhadap kadar alkaline phosphatase. Mutiara Medika. 2008;8(2):89-95.

8. Maiza-Benabdesselam F, Khentache $S$, Bougoffa K, Chibane M, Adach S, Chapeleur Y, et al. Antioxidant activities of alkaloid extract of two algerian species of Fumaria: Fumaria capreolata and Fumaria bastardii. Rec Nat Prod. 2007;1(2-3):28-35. 